\title{
FACTORS AFFECTING CONSUMERS PURCHASE DECISION: A CASE STUDY IN CAR MARKET IN HO CHI MINH CITY
}

\author{
Le Thanh Tung*, Lam Thanh Hieu, Nguyen Minh Phuc \\ Faculty of Business Administration, Ton Duc Thang University, Ho Chi Minh city, Vietnam. \\ No. 19 Nguyen Huu Tho, Tan Phong ward, District 7, Ho Chi Minh city, Vietnam. \\ *Corresponding author: lethanhtung@tdt.edu.vn
}

\begin{abstract}
:
This paper aims to examine the factors affecting purchase decision cars of consumers to enable car manufacturers to find out the possible vulnerability between the expectations of customers and products on the market. The research uses a random survey with a group of 271 consumers in Ho Chi Minh City. Results of factor analysis and regression show that three factors including: safety features, reliability and resale value actually have positive impact on the purchasing decision automobiles consumer. On the practical significance, the study proposes some solutions to help manufacturers and distributors offering reasonable policies in order to improve sales, profits, expanding markets in Vietnam. Besides, the study also has some limitations, so the next study should be expanded and further research to be able to explain more of the factors affecting purchase decision cars of consumers.
\end{abstract}

Key words: purchase decisions, cars, Ho Chi Minh City, Vietnam.

\section{INTRODUCTION}

According to World Bank' report (2014) the Vietnam auto industry will have the fastest growth of all in Southeast Asia over the next 20 years. This growth will be the result of increasing consumer demand, a young workforce, and strong governmental support for the industry. This report also shows that Vietnam's auto industry will annually produce 220,000 units by 2020 and 1.5 million units by 2035. The development of this industry will enable our country to save significant amounts of foreign currency for imports, contributing to reduce the annual budget deficit, improve quality of life of people and contribute to promoting economic development. Vietnam in terms of deeper integration with the international community and the growing number of middle-class consumers have attracted the attention of car manufacturers and marketers.

Official figures from the Vietnam Automobile Manufacturers Association (VAMA) shows that automotive sales in Vietnam reached 157,810 vehicles in 2014, up 43\% compared to 2013. The statistics of VAMA continue recorded impressive growth of automobile sales in Vietnam's market in 
the first six mouths of 2015 reached 103,000 vehicles (increased 60\% compared to the first six mouths of 2014).

This paper aims to research the factors affecting the purchase cars and learn the sychology and behavior of current customers with a sample of group comsumers in Ho Chi Minh city (HCMC). Since then driven for businesses in the design and manufacture of vehicles and services meet market expectations in order to promote the production and use of automobiles.

Knowledge of the buying behaviour of the different market segments helps a seller to select their target segment and evolve marketing strategies to increase the sales. Advertisers and marketers have been trying to discover why and what consumers buy. This research tries to analyze the influence of perception in the consumers mind and how this information can be used successfully by marketers to gain entry into the minds of the consumers. In this study we try to focus three following objectives including:

1. To gain knowledge about consumer decision making process, especially with high involvement products

2. To identify and analyze the factors influencing the purchase decision cars of consumers.

3. To research the behaviour of consumers, perception of product attributes and level of satisfaction.

The structure of this paper is organized as follows. Section 2 is an overview of literature and model research. Section 3 presents methodology and data. Section 4 reports the research results and discussion. Section 5 includes conclusions and policy recommendations. Finally, section 6 comments some limitations of this research.

\section{LITERATURE REVIEW AND MODEL RESEARCH}

Aaker (1996) showed brand has a value and it depend on the quality of its products in the market and the satisfaction of the customer in its products and services. This study provides the trust of the customers in the brand. If customers trust a brand quality it makes a positive connection to the brand and customers will have a reason to become a loyal to the brand. Loyalty and trust of the customers is very important for a company because it reduces the chance of attack from competitors.

Adithya (2013) identified that value for money and satisfaction are the two important factors for purchase of passenger cars. Brand name followed by popularity is the most frequent basis of selection of a brand. Advertisements are the main sources of knowledge about latest brands and trends. Brand is revealed that when consumer purchases a car, brand names do influence his/her choice (Alamgir et al., 2010). The study also reveals 
that branded cars have a great place in consumer mind, when customers go for purchasing a car, they prefer to purchase a well known branded car. Customers do not want to try new or unknown branded cars because they have not much information about the lesser known brand.

Anandh and Sundar (2014) found that value, comfortability, efficiency, accessibility, ambition and need are positively influencing the consumer's overall satisfaction about small cars. Therefore, the small car manufacturers should also focus on value-creating activities as such so that consumers will have a better perception of quality of the brand. By incorporating these factors, it also delivers a functional benefit such as creating a differentiation from industry competitors. They have to find out better quality and low cost product because Indians are conscious about the price and fuel efficiency. Archer and Wesolowsky (1996) have carried out a logit analysis of events pertaining to a critical incident model which demonstrates how quality in both the product and its supporting services, as well as the interactions between these factors, can affect owner intentions regarding future purchases. Proactively creating positive service incidents and avoiding negative service incidents can help improve customer loyalty to the service agent and manufacturer.

Armstrong and Kotler (2011) showed that reliability and quality are interrelated, perceived quality has direct impact oncustomer purchase decision and brand loyalty especially during the time customers have less or no information of the products that they are going to purchase. Banerjee et al. (2010) concluded that household income is the prime factor of the number and size of cars that household buys, besides that family size is proved to be irrelevant factor as it was found that smaller vehicles were preferred even by larger family. Baumgartner and Jolibert (2008) revealed that the car produced in West Germany received the highest rating on firm attitudes namely acceleration, safety, styling and workmanship among the Americans. At the same time, the Japanese car ranked highest on fuel economy and reliability. Bhuwan and Nisha (2013) have solved problem aspect regarding customer satisfaction. Overall, customers are satisfied with that cars they use but they also want to satisfied a various internal and external factors like extra care facilities, location of the shops, various information provided by car dealers, advertisement and print media promotions, features of the car in all are contributing in making car purchasing behaviour of customers. Companies need to focus on improve the quality level of their services, develop the loyalty program between dealer and customers, customers and car companies.

Brown et al. (1987) analyzed the country of origin plays a significant role in the consumers' behaviour. The brand name, lower price and distributor's reputation have a significant impact on the sale of passengers' car. According to Capgemini (2009) the top four factors that consumers continue to claim they value when making vehicle purchasing decisions are reliability, safety, price, and fuel economy. Besides, consumers are increasingly using the Internet to search for vehicle pricing information and are wanting to buy new vehicles online as an alternative to the traditional dealer model. Chidambaram and Alfred (2007) unveiled the customers believe that the brand name inform them something about product quality, utility, technology and they prefer to purchase the 
passenger Automobiles which offer high fuel efficiency, good quality, technology, durability and reasonable price.

Ernst \& Young Global Automotive Centre (2010) reported that consumer demand for green products is growing. There is growing awareness of fuel-efficient and alternative fuel vehicles, and consumer research indicates a growing interest in purchasing more fuel efficient and low emissions "greener" vehicles. Consumer research shows that fuel savings is the primary factor influencing decisions to purchase green vehicle with concern about environmental impacts showing up as a secondary factor. Intrinsic product attributes which may be used to evaluate quality include performance, features, reliability, conformance, durability, serviceability, aesthetics and image (Garvin, 1987). Extrinsic attributes include price, warranty, advertising and brand name. It has been found that factory workers, managers, sales personnel and consumers differ widely in which attributes they believe are best used to describe product quality (Morgan, 1985). Guiles (2008) identified that fuel economy and lower maintenance cost have its impact on the consumers' behaviour towards the passenger car.

Gupta (2013) revealed the strong influence of attributes like price, fuel efficiency and powerful engine in buying decision and importance of reference group Beside the friends, family and relatives as main influencer, users also trust the information available on internet). Also, price-off amongst the promotional offers and fuel efficiency in the passenger cars are found to be the foremost reasons for the preference by the customers. The study also reinforced the association between the respondents' age and the main influencer in buying a passenger car. Consumers felt that if the price of the passenger car is ignored, they will prefer premium level, stylish and powerful passenger car. Hampton and Schiller (1987) improved vehicle quality, competition in quality is more than just the quality of the vehicle itself; it includes marketing and sales activities as well as after-sales provision of warranty and maintenance service. Evaluation of the impact of these activities on customer satisfaction determines where improvements are needed. Harris (2001) affirmed that in terms of safety, consumers consider safety to be one of the most important considerations in buying a new or used vehicle. The vehicle safety performances are ratings before purchasing a vehicle. In addition, consumers are increasingly seeking safety features in their and are willing to pay more for a vehicle to obtain improved safety levels.

Jahanshahi et al. (2011) showed that the quality of customer service and the quality of products promotes customer satisfaction, and also there is a positive relationship between customer satisfaction and customer loyalty in the context of the Indian automotive industry. John and Pragadeeswaran (2013) found that demographic factors like age, gender, education, status and income influence consumers indirectly for small car buying preference. Value consciousness and price quality inference are the important factors which influence small car buying. Kaur and Sandhu (2006) attempted to find out the important features which a customer considers while going for the purchase of a new Automobile. The respondents perceive that safety and comfort are the most important features of the passenger Automobile followed by luxuriousness. 
Keller (2012) researched the customers follow the sequence of steps in decision process to purchase a specific product. They start realizing a requirement of product, get information, identify and evaluate alternative products and finally decide to purchase a product from a specific brand. When customers purchase particular brand frequently, he or she uses his or her past experience about that brand product regarding performance, qualityand aesthetic appeal. Lee and Govindan (2014) indicated that the three independent variables of car's reliability, safety, and price significantly influence consumer buying behaviour towards national cars in Kuala Lumpur. Leslie and Malcolm (2003) evidenced brands also have a symbolic value which helps the people to choose the best product according to their need and satisfaction. Usually people do not buy certain brands just for design and requirement, but also in an attempt to enhance their self esteem in the society. Luniya and Verghese (2013) found that price, resale value, mileage, easy financing,comfort and safety, models of the cars are various factors that influence the purchase preference of consumers while purchasing a car. Among these variables mileage, easy financing and model of the car have significant influence on customers while buying a car. There is no doubt that consumers do care about fuel costs, do value fuel economy, and that their interest in fuel economy increases when fuel prices increase (Mahadi and Gallagher, 2009).

Marken (2003) affirmed branding starts when company designs a product with great feature and capabilities better than what their competitors are offering. The company then has a "position" in a product distinct category against competitors. The problem increases when neither of the groups has made efforts to create emotional bond between the customers and the company and its product. Emotional branding is the fine approach that clarifies the values of the company to the customers. Mathe and Shapiroo (1993) showed that the provision of good quality warranty support and maintenance services to durable goods customers is important to the success of these goods in the marketplace. Menon and Raj (2012) found that in the information gathering and consumer purchase initiation stage, TV commercials on car models and brands, search on internet website of the manufacturer and visit to dealers /distributors were the prime sources where customers gathers information on car models.

Monga, Chaudhary and Tripathi (2012) indicated the brand image and brand personality complement each other and the brand perception aids the building of brand images. Najeemudeen and Panchanatham (2014) found that customers prefer petrol and diesel cars alike; Driving cum Travel comfort is the prime factor that the customers are looking for while selecting their car; Mileage, Interior Space and Resale value are the other influencing features; Public opinion or suggestions from referral group is the prime factor that influences the customers' purchase decision of cars including: price, brand name, style and design of the car. Advertisements, availability of service and spare parts facilities nearby are also important. Beside, salesman's personality and communication skills also influence the customers. But without a good public review no any offer or cash discount can help the car marketer to boost the sale. Sasikumar and Sriram (2013) reported that the preference of a given brand can be explained in terms of six factors namely Product reliability, monetary factor, trendy appeal, 
frequency of non-price promotions offered, trustworthiness and customer feeling or association towards brand. Rezvani et al. (2012) demonstrated that people care about which country products come from and where they are made and consider these factors when evaluating the quality of product. Stereotypes of country and the preferences of customers, influence the purpose intention. Political system, culture and the economy of the country can be a cause of sensitivity to people. in addition, there is no doubt that country of origin has considerable influence on the purchase intention process.

Solomon (2007) affirmed the people who have the financial ability to afford expensive brands not only just to consume the products but also to show off with the view to inspire envy among others. Conspicuous consumption is related to the person's social class, generally the upper class consumer would purchase and display exclusive items to show-off their wealth and power. They purchase expensive branded products like cars, latest electronics even if it is not necessary for them to purchase. White (2004) discussed the factors those plays a vital role in choice of car buyers and observed that consumer negotiate with dealers over price and pursue them to every extent to avail incentives as well as low-interest payment plans. Woods (2010) found that vehicle reliability has a positive impact on the consumers' likelihood of choosing a vehicle. Srivastava and Tiwari (2011) showed that customers considered Price, Safety, Comfort, Power and Pickup, Mileage, Max Speed, Styling, After Sales Service, Brand Name and Spare Parts Cost. Also word of mouth publicity and advertisements in car magazines are more effective communication medium for promotion of Cars. Subadra et al. (2010) identified that driving comfort and fuel economy are the most important features of a passenger car followed by availability of spare parts and price of the car. Teng (2009) showed customers preference to purchase the product, whose image is very close to customer. Moreover customers are well aware of certain brand name through advertising, nfrom their past experience or information form their friends and relatives.

Timothy and Kearney (2006) concluded the main characteristics consumers weigh in their vehicle purchase decision include fuel economy, purchase price, maintenance and reliability, safety, performance and personal or family needs. Vidyavathi (2012) indicated the demand for small automobile segment is increasing because of the growing number of nuclear families. The study analysis shows that the brand image and brand loyalty could be boosted by selling quality automobiles at a reasonable price to suit the needs of the middle income grou Automobile owners feel that the hospitality shown by the dealers is more during their visits to the places of dealers before and immediately after the purchase. But after some time they face a problem with their dealers regarding after sales service. Therefore, it is suggested that the services should be properly explained, friendly approach and reliability in service are to be further improved. Most of the respondents expressed that they have technical problems in their existing automobile and some of them opined that they switch over to another brand because they would like to buy a new technology automobile. They perceived that driving comfort and fuel economy are the most important features of the passenger automobile followed by availability of spare parts, price, easy installments and reasonable interest rates. 
Based on some previos researchs and the specific characteristics of consumers in HCMC, we propose a model of factors affecting purchasing decision cars of consumers:

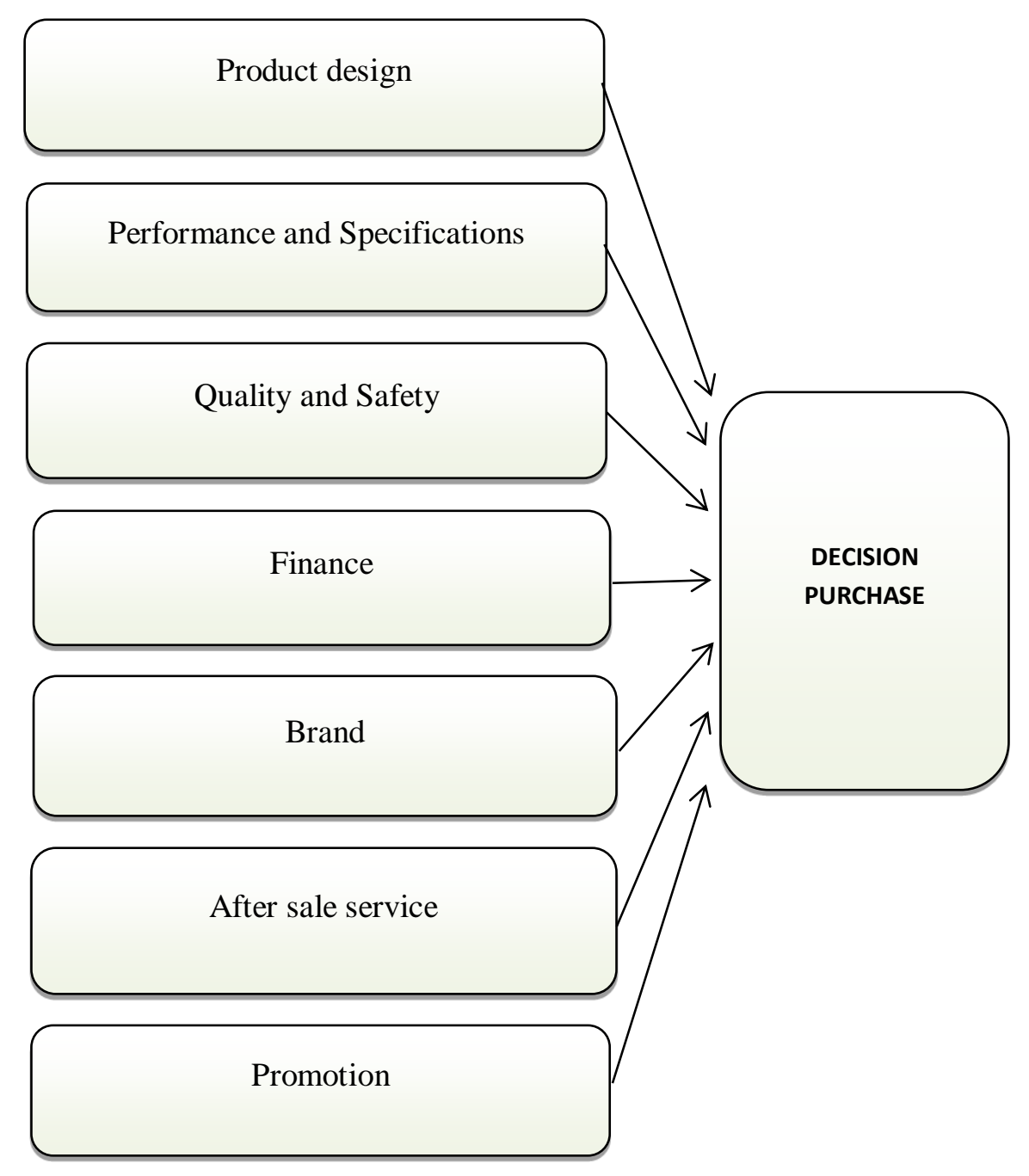

Figure 1: Research model

\section{METHOLODOGY AND DATA}

This research applies both qualitative and quantitative methods to investigate the factors that affect the purchase decision cars. Qualitative methods applied included group discussion and in-depth interview with specialists as well as customers to explore, develop and adjust the measurement scale. Quantitative methods included Cronbach's Alpha, EFA and linear regression to test the reliability of the scale and figure out the relationship among the factors in the research model. Preliminary scales were built including one dependent variable is Purchase decision and 7 independent variables. Quantitative questionnaire (Table 1) consists of 31 observed variables using Likert 5 point scale (1: Very unimportant; 5: Very important). 
Table 1: Main factors affecting purchase decision cars

\begin{tabular}{|c|c|}
\hline Factor & Variables \\
\hline \multicolumn{2}{|c|}{ Purchase decision } \\
\hline PUR1 & I am planning to buy a car for my family \\
\hline PUR2 & I am trying to find buyers for my family car. \\
\hline PUR3 & Buy car is my top concern. \\
\hline \multicolumn{2}{|c|}{ Product Design } \\
\hline DES1 & Luxurious shape with impressive contours of car for me to assert myself. \\
\hline DES2 & Aestheticism and style of the car strongly expressed position of the employer \\
\hline DES3 & I am interest in the color of the vehicle. \\
\hline DES4 & I was convinced by the spacious and comfortable vehicle. \\
\hline DES5 & $\begin{array}{l}\text { I am expressed with the exquisite, compact technology characterized by equpment in } \\
\text { vehicle. }\end{array}$ \\
\hline \multicolumn{2}{|c|}{ Functional, technical characteristics } \\
\hline TEC1 & Advanced engine car lead for perfect driving experience. \\
\hline TEC2 & Vehicle fuel is the problem I noticed. \\
\hline TEC3 & Fuel saving is an important factor leading. \\
\hline TEC4 & The smart technology features gives me interesting experience \\
\hline TEC5 & The cars have certified environmental friendly is highly appreciate \\
\hline \multicolumn{2}{|c|}{ Quality and safety } \\
\hline SAF1 & Durability is what I expect most \\
\hline SAF2 & Sitting in the car and drive to feel safe is the key fact \\
\hline SAF3 & Awards and honors of the car as much as give me highly reliability. \\
\hline SAF4 & The moderm emergency equipments relief gives me more peace of mind. \\
\hline SAF5 & The certification standards of vehicle is information I always care. \\
\hline \multicolumn{2}{|c|}{ Finance } \\
\hline FIN1 & $\begin{array}{l}\text { Selling price consistent with the finance capacity of the family is the most important } \\
\text { factor. }\end{array}$ \\
\hline FIN2 & I concerned with selling prices of vehicle on the market \\
\hline FIN3 & Taxes, Fee of the cars is the matter that should be considered \\
\hline
\end{tabular}




\begin{tabular}{|c|c|}
\hline FIN4 & I care about informations of Interest rates and bank lending procedures \\
\hline \multicolumn{2}{|l|}{ Brand } \\
\hline IMA1 & Car brand in the market gives me confidence. \\
\hline IMA2 & I am interest in the original country of the brand. \\
\hline IMA3 & I wist that the brand which was selected is trusted \\
\hline IMA4 & The popularity of the brand shows my high class \\
\hline IMA5 & I was convinced by the positive contribution to society by Manufacturer. \\
\hline IMA6 & Higher resale prices was notable. \\
\hline \multicolumn{2}{|c|}{ After sale service } \\
\hline AFT1 & I was attracted by the convinienced and quick after-sale service \\
\hline AFT2 & System-wide warranty services is essential. \\
\hline AFT3 & Reasonables repair cost is notable. \\
\hline AFT4 & The price are reasonable and the available of spare parts is an important factor \\
\hline \multicolumn{2}{|c|}{ Promotion } \\
\hline PRO1 & Other form of promotions increase the attractiveness \\
\hline PRO2 & Advertising impression will bring positive emotions \\
\hline PRO3 & I appreciate the professionalism and caring attitude of the saleman \\
\hline PRO4 & High frequency of the brand on the public communication increase the level of interest \\
\hline PRO5 & I was attracted by the professional website of Manufacture Agency \\
\hline
\end{tabular}

Source: Compiled from the relevant research

Respondents are customers who live in HCMC and bought cars under 1 year from the time of the survey. Data from the research were collected within 2 months from the date 27/01/2015 to date 27/03/2015. Using a random survey coupons directly to consumers. After conducting a survey of the actual figures may be used to conduct the analysis was 271 (votes $71.5 \%$ ).

Table 2: Respondents' Demographic Characteristics

\begin{tabular}{|llll|}
\hline Characteristics & & Frequency & Percentage (\%) \\
\hline \multirow{2}{*}{ Gender } & Male & 152 & 56,1 \\
& Female & 119 & 43,9 \\
\hline \multirow{3}{*}{ Age Group } & Under 35 years & 47 & 17,3 \\
& 36 - 45 years & 141 & 52,0 \\
& Over 46 years & 83 & 30,6 \\
\hline
\end{tabular}




\begin{tabular}{|c|c|c|c|}
\hline \multirow{2}{*}{ Marital Status } & Single & 51 & 18,8 \\
\hline & Married & 220 & 81,2 \\
\hline \multirow{5}{*}{ Occupation } & Teacher & 4 & 1,5 \\
\hline & business man & 122 & 45,0 \\
\hline & Civil servants & 47 & 17,3 \\
\hline & Officer & 43 & 15,9 \\
\hline & other & 55 & 20,3 \\
\hline \multirow{3}{*}{ Income } & Less 20 million VND & 51 & 18,8 \\
\hline & $20-30$ million VND & 97 & 35,8 \\
\hline & Over 30 million VND & 123 & 45,4 \\
\hline \multirow{12}{*}{ Brand } & Toyota & 58 & 21,4 \\
\hline & Audi & 11 & 4,1 \\
\hline & Chevrolet & 26 & 9,6 \\
\hline & $\mathrm{Kia}$ & 19 & 7,0 \\
\hline & Ford & 33 & 12,2 \\
\hline & BMW & 16 & 5,9 \\
\hline & Nissan & 17 & 6,3 \\
\hline & Mazda & 4 & 1,5 \\
\hline & Honda & 37 & 13,7 \\
\hline & Mercedes-Benz & 36 & 13,3 \\
\hline & Hyundai & 10 & 3,7 \\
\hline & other & 4 & 1,5 \\
\hline \multirow{7}{*}{$\begin{array}{l}\text { Reference source of } \\
\text { information }\end{array}$} & Sellers & 55 & 20,3 \\
\hline & Family/friends & 96 & 35,4 \\
\hline & Internet & 67 & 24,7 \\
\hline & Magazine & 38 & 14,4 \\
\hline & Ads on TV & 4 & 1,5 \\
\hline & Event producer / agent organization & 7 & 2,6 \\
\hline & other & 4 & 1,5 \\
\hline
\end{tabular}

Source: Calculated from the research data

The results show that car buyers often is business man (45.0\%), aged between 35 and 45 (52.0\%), married (81.2\%), income over VND 30 million /month (45.4\%) and reference source of information from family/friends (35.4\%). These are the target customers that the car manufacturers toward demand and their tastes for goods vehicles is highest.

We further analyzed the data collected by testing coefficient reliability Cronbach's Alpha, using the method of factor analysis EFA and regression analysis to test the hypothesis and research model recommended, since it could give the necessary recommendations.

\section{RESULT AND DISCUSSION}

\subsection{Scale testing}

We assess the reliability of the scale in the sample size was $n=271$ to confirm the scale for the concept research is appropriate. Analytical results Cronbach's Alpha of the scale is presented in Table 3 
Table 3: The results of Cronbach's Alpha of scales

\begin{tabular}{|lcc|}
\hline \multicolumn{1}{|c|}{ Factors } & N of items & Cronbach's Alpha \\
\hline Purchase variable (PUR) & 3 & 0,728 \\
Product Design variable (DES) & 5 & 0,721 \\
Công năng, đặc tính kỹ thuật variable (TEC) & 5 & 0,730 \\
Quality and safety variable (SAF) & 5 & 0,627 \\
Finance variable (FIN) & 4 & 0,413 \\
Branch variable (IMA) & 6 & 0,680 \\
After sales service variable (AFT) & 4 & 0,581 \\
Marketing activities variable (PRO) & 5 & 0,797 \\
\hline
\end{tabular}

Source: Calculated from the research data

After eliminating factors of finance and after-sales service, this result shows that almost all the scales measuring remaining satisfactory, since the observed variables of the scale are coefficients Cronbach's Alpha greater than 0.6.

After 4 times exploring factor analysis EFA, with 4 variables excluded from the model because load factor factor (Factor loading) $<0.5$. Continuoustly, $\mathrm{KMO}=0.715$ coefficient and $72435 \%$ of the total variance extracted. Thus, $72435 \%$ of the data variance is explained by the 8 factors.

Table 4: EFA Analysis

\begin{tabular}{|c|c|c|c|c|c|c|c|c|}
\hline \multirow[t]{2}{*}{ Variables } & \multicolumn{8}{|c|}{ Component } \\
\hline & 1 & 2 & 3 & 4 & 5 & 6 & 7 & 8 \\
\hline SAF2 & 0,801 & & & & & & & \\
\hline SAF1 & 0,756 & & & & & & & \\
\hline TEC3 & 0,715 & & & & & & & \\
\hline IMA1 & 0,542 & & & 0,310 & 0,338 & & & \\
\hline TEC4 & & 0,826 & & & & & & \\
\hline SAF4 & & 0,709 & & & & & & \\
\hline TEC5 & & 0,598 & & & & & & 0,322 \\
\hline SAF5 & 0,337 & 0,542 & & & 0,365 & & & \\
\hline TEC2 & 0,478 & 0,518 & & & & & & \\
\hline DES2 & & & 0,864 & & & & & \\
\hline DES1 & & & 0,824 & & & & & \\
\hline DES3 & 0,464 & & 0,595 & & & & & \\
\hline IMA4 & & & & 0,790 & & & & \\
\hline IMA5 & & & & 0,638 & & & $-0,459$ & 0,364 \\
\hline IMA2 & & & & 0,620 & & $-0,306$ & & \\
\hline PRO5 & & & & & 0,859 & & & \\
\hline IMA3 & & & 0,323 & & 0,573 & & & \\
\hline
\end{tabular}




\begin{tabular}{|l|llll|}
\hline PRO4 & & \multicolumn{3}{|c|}{0,737} \\
PRO1 & & 0,736 & \\
\hline DES4 & & \multicolumn{3}{|c|}{0,854} \\
DES5 & 0,383 & 0,450 & 0,503 & \\
\hline IMA6 & & & & 0,804 \\
\hline
\end{tabular}

Source: Calculated from the research data

Results final factor analysis for comparison with the observed variables of the components in the model scale official studies show that the variables are drawn into eight factors. So we will edit the name of factors

Table 5: Named for the independent variables

\begin{tabular}{|c|l|}
\hline Factor & Name of factor \\
\hline F1 & Reliability and the ability to save fuel \\
\hline F2 & Safety \\
\hline F3 & External shape and style of car \\
\hline F4 & Brand \\
\hline F5 & Reliability \\
\hline F6 & Promotion \\
\hline F7 & Furniture \\
\hline F8 & Resale value \\
\hline
\end{tabular}

Source: Calculated from the research data

\subsection{Linear multivariate regression}

Results of linear regression analysis in this research was performed on SPSS 16.0 statistical software with the estimation method ordinary least squares method and ENTER (simultaneously). Eliminating variables sig respectively $>0,05$ from high to low and the result is:

Table 6: Results of linear multivariate regression

\begin{tabular}{|lllll|}
\hline \multicolumn{1}{|c}{ Variable } & $\begin{array}{c}\text { Unstandardized } \\
\text { Coefficients }\end{array}$ & $\begin{array}{l}\text { Standardized } \\
\text { Coefficients }\end{array}$ & Sig. & VIF \\
\hline PUR & 0,375 & & 0,000 & \\
F2 & 0,113 & 0,406 & 0,000 & 1,154 \\
F5 & 0,106 & 0,130 & 0,024 & 1,167 \\
F8 & $-0,015$ & 0,095 & 0,079 & 1,030 \\
\hline Adjusted $\mathrm{R}^{2}$ & \multicolumn{5}{c}{0,234} \\
\hline
\end{tabular}

Source: Calculated from the research data

Final regression equation as follows: PUR $=0,406 * \mathrm{~F} 2+0,130 * \mathrm{~F} 5+0,095 * \mathrm{~F} 8$ 
The model explains only $23.4 \%$ of these factors influence the decision to buy cars, the remaining $76.6 \%$ of the dependent variable variation is due to other factors explain. The correlation coefficient between the variables are VIF smaller absolute value $<10$. So we conclu not exist multicollinearity in model

\section{CONCLUSION AND RECOMMENDATION}

After 8 factors extracted, the results of regression analysis found three factors that have a positive impact on the decision to buy cars are: F2: Safety features, F5: Reliability, F8: Resale value (F2, F5 statistically significant at the 5\%; F8 with statistical significance at 10\%). If we compare the impact of these variables on the purchasing decisions we see standardized beta of F2 - safety features is the largest $($ Beta $=0.406 \mathrm{sig}=0.000$ and $<0.05)$. Thus, the safety features the strongest impact on vehicle purchase decisions of customers, and to F5 -

Reliability $($ Beta $=0.130 \mathrm{sig}=0.024$ and $<0.05)$ and finally F8 - Resale Value (Beta sig $=0.079=0.095$ to $<0.1)$.

From the findings, we propose a number of measures to bring research results into production and business processes in the automotive business as follows:

The first, the majority of those surveyed feel that driving comfort and fuel economy are the most important features of the vehicles that interest them. Therefore manufacturers should design products to maximize these factors. In addition to fuel saving car manufacturers should also focus on looks and style of the cars may attract consumers. With the current trend is developing nuclear family, the car manufacturer should consider the production of family cars have shape, size, safety, operational features interior and features Family friendly. The car manufacturers need to supply a variety of types, models and designs of cars to meet the customer's needs through to not overlook any given market segment.

The second, designing the interior a spacious, modern facilities, tidy will add comfort to the user. Advanced features, performance, features modern, rescue equipment, machinery, intelligent instruments to enhance enjoyment and satisfaction to our customers. However, it must be environmentally friendly and life. Despite higher selling prices compared to many countries, but safety standards for automobiles in Vietnam market are set very low. System safety standards in Vietnam was still quite inadequate, because the standard based solely on the manufacturers give not have its own set of rules and safety standards. So should soon offer a roadmap to improve safety standards have required such as ABS, airbags, electronic stabilization system ... In this way new media is enhanced ensure quality commensurate with road and world trends. Accompany it with the safety features must be continuously improved in order to entice customer loyalty towards them. Since we can positively impact the purchasing decision of consumers better.

The third, to ensure that the products find a perfect position in the minds of customers, the manufacturers should be positioning their products through advertising activities, appropriate promotion and sales promotion. Give claim her product positioning and activities such as car manufacturers the most reliable ... 
Along with building a distribution network of environmentally friendly, comfortable and enthusiastic in dealers with a staff of professional sales to generate the excitement and satisfaction to our customers. Manufacturers should build a network of showrooms, dealers must achieve high standards, with showroom, parts store and repair large-scale, salespeople are trained. Expanding its brand through exhibition, introduce the product. Need specifying clearly the papers certificates of origin, brand. Should exhibit, promote the awards that the company achieved.

The fourth, the research shows that customers wishing to purchase cars and learn reference information via the Internet fairly high proportion $(24.7 \%)$, so the manufacturers and dealers need to invest appropriately have an attractive website and attract customers, especially the main website as this is the face of your business. Besides to design a simple graphical interface, easy to read and easy to understand for customers. Also speed is also noticeable problem. The research also indicates that women car buyers also demand accounted for $43.9 \%$ fairly large, this is the strategic market segments that many manufacturers need to care for sex have a huge impact on decided to buy the car. Run the program more information exchange between automotive manufacturers, resellers and gallery owners to connect between buyer and seller. Together manufacturers and dealers should develop information flow in its distribution system to be able to listen to the opinions of customers to continuously improve our products, test and evaluate the products before giving market regrettably avoid risks to customers when using the product. That will contribute to increase the confidence of our customers for products as well as trust in business.

The last, for domestic enterprises: To compete with foreign products, the domestic manufacturers to really entice consumers back to himself by the quality, design and merchandise. Constantly improving technology, improving productivity and quality, and product designs to better meet consumers' requirements. Changing habits, consumer psychology, inspire patriotism, formed the habit of using domestic goods. The employers also have to build their own business motto right and create genuine confidence in the hearts of consumers. Diversification of product design, to create cars with eye-catching design and attractive while maintaining the core values of the brand. To increase investment in technological innovation to improve manufacturing processes, distribution network expansion.

\section{LIMITATIONS OF THIS RESEARCH}

Besides the contributions, this study also has some certain limitations are:

(i) Due to objective conditions, the study is performed according to convenience sampling method therefore not representative of the impact of research statistics are not fully reliable. Hence the next research may choose other methods to data thuthap representative and more generalized. (ii) The search for reference is limited, so there are some other factors that may impact but has not been studied to. So there should be more studies on this issue in order to improve further scales. (iii) The study used a scale from foreign studies, some 
factors will not suitable for Vietnam market, so the ability to generalize the findings are not high. Research may be conducted only in HCMC market. (iv) The ethos of the culture, economy, society different in each market is different, so there may be difference. So research proposals should be expanded throughout the country Vietnam.

\section{REFERENCES}

Aaker (1996), Building strong brands, New York Free Press,

Adithya (2013), Consumer Perception and Behaviour of Car Owners - An Empirical Study in Bangalore City, Global Business Analysis International, 2(1), 104-107

Alamgir et al. (2010), Influence of brand name on consumer decision making process - an empirical study on car buyers, The USV Annals of Economics and Public Administration Journal, 10(2), 142-153.

Anandh and Sundar (2014), Factors Affecting Consumer's Brand Preference of Small Cars Exploratory Factor Analysis, IOSR Journal of Business and Management, 16(5), 43-47

Archer and Wesolowsky (1996), Consumer response to service and product quality: A study of motor vehicle owners, Journal of Operations Management, 14, 103-118

Armstrong and Kotler (2011), Principles of Marketing, 14th ed., Prentice Hall of India, New Delhi

Banerjee et al. (2010), New vehicle choice in India: household choice among motorized vehicle segments, 12th WCTR, Lisbon, Portugal 1

Baumgartner and Jolibert (2008), Consumer Attitudes Towards Foreign Cars, Journal of International Business Studies II, 71-80.

Bhuwan and Nisha (2013), Consumer Perceptions and Behaviour: A Study with Special Reference to Car Owners in Alwar District, International Journal of Scientific Research and Reviews, Special Issue, 167- 189

Brown et al. (1987), Attitudes towards European, Japanese and US cars, European Journal of Marketing, 21(5), 90-100

Capgemini (2009), Cars Online 09/10: Understanding Consumer Buying Behavior in a Volatile Market

Chidambaram and Alfread (2007), A Study on Brand Preference of Passenger Car with Reference to Coimbatore City, Indian Journal of Marketing, 34(9), 30-39.

Ernst and Young Global Automotive Centre (2010), Gauging interest for plug-in hybrid and electric vehicles in select markets.

Garvin (1987), Competing on the Eight Dimensions of Quality, Harvard Business Review, 65, 101-109.

Guiles (2008), Fuel Economy takes a hack seat as cars get faster and more fun, Wall Street Journal, October, 33

Gupta (2013), A Study of Buying Decision Influencers for Passenger Car Segment in New Delhi, International Journal of Business and Management Invention, 2(12), 64-71 
Hampton and Schiller (1987), Why Image Counts: A Tale of Two Industries, Business Week, Jun. 8, Industrial/Technology ed., 138-140

Harris (2001), The fourth survey of attitudes of the American people on highway and auto safety, Washington, DC:

Jahanshahi et al. (2011), Study the Effects of Customer Service and Product Quality on Customer Satisfaction and Loyalty, International Journal of Humanities and Social Science , 1(7), 253-260

John and Pragadeeswaran (2013), A study of small car consumer preference in pune city, TRANS Asian Journal of Marketing and Management Research, 2(4), 1-14

Kaur and Sandhu (2006), A Study on Factors Influencing Buying Behaviour of Passenger Car Market, Paradigm, 8(2), $69-77$

Keller (2012), Strategic Brand Management, 4th ed., Prentice Hall

Lee and Govindan (2014), Emerging Issues in Car Purchasing Decision, Academic Research International, 5(5), 169-179

Chernatory and McDonaid (2003), Creating Powerful Brands: The Strategic Route to Success in Consumer, Industrial, and Service Markets, 3rd ed., Oxford, Butterworth Heinemann

Luniya and Verghese (2013), Consumers Purchase Preference and Its Determinants : An Empirical Study on 4-Wheelers in Chhattisgarh, The Pacific Business Review, 6(2), 48-52

Mahadi and Gallagher (2009), Fuel Prices and Consumer Preferences for Vehicles, Transportation Research Record: Journal of the Transportation Research Board, Issue 2139, 31-37

Marken (2003), Emotional Branding How Successful Brands the Irrational Edge, Public Relations Quarterly, 48(2), 12-25

Maslow (1943), A Theory of Human Motivation, Psychological Review, 50, 370-396

Mathe and Shapiro (1993), Integrating Service Strategy in the Manufacturing Company, $1^{\text {st }}$ ed., Chapman and Hall

Menon and Raj (2012), Dominant partial Least square factors of consumer behavior of passenger cars, Asian Journal of Management Research, 3(1), 83-99

Monga, Chaudhary and Tripathi (2012), Car Market and Buying behavior - A study on Consumer Perception, International Journal of Modelling Identification and Control, 2(2), p 44-63

Morgan (1985), The importance of quality, Perceived quality: Institute of retail management, New York University, J. Jacoby and J.C. Olson (Eds), Lexington, MA: Lexington Books, 61-64.

Najeemudeen and Panchanatham (2014), A study of consumer perception and behaviour towards passenger cars in Tirur, International Journal of management focus, 4(2), 31-37

Sasikumar and Sriram (2013), A Study of Customers Brand Preference in SUVS and MUVS: Effect on Marketing Mix Variables, International Referred Research Journal, 4(1), 48-58 
Rezvani et al. (2012), A Conceptual study on the country of origin effect on consumer purchase intention, Asian Social Science, 8, 205-215.

Solomon (2007), Customer behavior, 7th ed., Prentice Hall of India, New Delhi

Srivastava and Tiwari (2011), A Study of Behavior of Maruti SX4 and Honda City Customers in Jaipur, Pacific Business Review- Quarterly Referred Journal, 3(4), 1-10

Subadra, Murugesan and Ganapathi (2010), Consumer Perceptions and Behaviour: A Study with Special Reference to Car Owners in Namakkal District, Asia Pacific Journal of Research in Business Management, 1(3), $37-60$

Teng (2009), A Comparison of Two Types of Price Discounts in Shifting Consumers Attitudes and Purchase Intentions, Journal of Business Research, 62(1), 14-21

Timothy and Kearney (2006), California Consumer and Fleet Manager Reactions to Clean Vehicle Technologies, Results from State-wide Focus Groups and Surveys.

Vidyavathi (2012), Customer Life Style Influence of Consumer Behavior with Reference to Automobile Industry in Chennai, Zenith International Journal of Multi disciplinary Research, 2(4), 37-50

White (2004), How people buy cars, Admap journal, 39(3), 41-43

Woods (2010), New Car Reliability Predicted, Consumer Reports 